\title{
Poder criativo e domesticação produtiva na estética piaroa e kaxinawá ${ }^{1}$
}

\author{
Elsje Maria Lagrou \\ Mestre em Antropologia Social pela USP \\ Professora de Antropologia da UFSC \\ “'Everyone wants to understand art', Picasso wrote, \\ 'why not try to understand the song of the bird?"'
}

(Geertz, 1983:94)

\begin{abstract}
Resumo: Neste artigo são comparadas as noções Piaroa e Kaxinawá de estética e o papel que estas possuem em suas sociedades enquanto discurso reflexivo. A "arte" e a estética por estarem em interação com outros sistemas simbólicos (a música, o ritual e a organização social), permitem apreender como são pensados o poder, o conhecimento e o parentesco nessas sociedades.
\end{abstract}

Unitermos: Etnologia, estética, poder, conhecimento, Kaxinawá, Piaroa.

A arte moderna tem sido enfática na defesa de sua independência de outros domínios da vida social. "A arte pela arte" é um credo tanto de artistas quanto dos que pretendem levar a arte a sério, e reflete nossa dificuldade ocidental de pensar a criatividade individual e a autonomia pessoal juntas com a vida em sociedade. Em nossa tradição pós-iluminismo, o artista assume a imagem do indivíduo desprendido, livre das limitações do "senso comum" sociocêntrico. O pensamento ocidental associa coletividade com coerção e se vê dessa maneira obrigado a projetar o poder de criatividade para fora da sociedade. Um resultado deste estatuto solitário de gênio é que o artista moderno perde, através de um uso idiossincrático de signos e símbolos, sua capacidade de comunicação: não há linguagem fora da sociedade ${ }^{2}$.

Overing afirma que:

"a visão contrastante da estética como domínio autônomo (mais um, ao lado da religião, ciência, economia e política) tende a ser nossa herança nas ciências sociais; 
apesar de termos na antropologia uma fraca "antropologia Da arte" que diz, timidamente, que outros povos, diferentemente de nós, não separam a arte, sua atividade e seu julgamento, do seu uso" (1989: 159).

Esta visão da arte e da estética tem duas consequiências: se a arte é um campo de experiência tão específico, do qual se pode falar somente em termos técnicos, intra-estéticos, não é tarefa nem a competência do antropólogo fazê-lo. É por isso que existem tão poucos estudos aprofundados sobre o tema. Por outro lado, se antropólogos decidem dizer algo sobre o assunto, o risco de um viés sociocêntrico é grande. Neste caso a arte é vista como reflexo e confirmação da estrutura social, algo sensível sem sentido e estrutura próprios, um código visual confirmando o que pode ser melhor dito em palavras. Esta visão "representativista" da arte obscurece a maneira dinâmica da arte agir sobre e dentro da sociedade, sendo um discurso silencioso sobre a condição humana e sua relação com os mundos naturais e sobrenaturais ${ }^{3}$.

Como um tipo específico de linguagem a arte conversa com outros sistemas simbólicos interligados (como música, ritual, mito, organização social) que se reforçam, contradizem e compensam mutuamente na encenação da vida em socieda$\mathrm{de}^{4}$. Desta maneira, a arte participa ativamente do discurso de uma sociedade sobre si mesma e pode nos ensinar muito sobre como as pessoas pensam e sentem a vida. Uma primeira colocação geral que pode ser feita sobre a estética nas sociedades indígenas, sem invalidar nossa ressalva feita a respeito da sua relativa independência, é que a estética permeia todos os aspectos da vida em comunidade e é altamente avaliativa. Saber o que as pessoas gostam e desgostam, descobrindo sua sensibilidade para certos fenômenos no seu ambiente, nos ensina, através de uma "etnografia do gosto", os símbolos chave desta sociedade, porque "as raízes da forma" se encontram na "história social da imaginação”(Geertz, 1983:119).

Neste texto compararei as idéias piaroa e kaxinawá sobre a condição humana, o poder, o conhecimento e o parentesco, a partir da sua estética.

A estética piaroa parece ser uma afirmação explícita do perigo do poder cultural descontrolado. O poder, quando fora de controle, se torna feio em comportamento e forma. A beleza está fortemente associada ao moralmente bom e socialmente domesticado. O poderoso nunca é belo em si mesmo. Para se torná-lo, precisa ser constantemente lavado de noite pela luz pura da lua e pelas palavras do canto do xamã. Este entendimento da estética como intimamente ligada à ética e à vida social é elaborada na mitologia piaroa.

A imaginação kaxinawá não faz uma associação tão explícita e inequívoca entre o moralmente bom e esteticamente belo. A beleza para os Kaxinawá é ligada ao poder e ao conhecimento e, através de ambos, à manutenção da saúde. O lado sedutor e perigoso da beleza é um tema recorrente na sua mitologia. O conceito de beleza visualiza para os Kaxinawá seu desejo e medo do estrangeiro poderoso. 
É importante, no entanto, marcar, desde o começo, uma distinção entre a prática e a imaginação social. Isto porque, nos seus julgamentos estéticos efetivos, os Piaroa e os Kaxinawá não diferem muito. Ambos valorizam moderação, limpidez e detalhe tanto no comportamento quanto no cuidado com o corpo, assim como no uso de desenho e adornos. A arte, em ambos os casos, está numa relação construtiva e não destrutiva com o sentido de comunidade e a criação de um modo de vida culturalmente apropriado. O estilo artístico não mostra nenhuma tendência de quebrar com a tradição porque a criatividade é vista sempre dentro, e nunca fora, de sua rede específica de sentidos sensíveis e sociais.

Os dois povos se assemelham não somente na sua praxis de julgamento estético mas também nos problemas ontológicos que enfrentam: a natureza do poder como uma coexistência inevitável de seus lados criativos e canibalísticos, assim como a recusa de aceitar o poder coercitivo e econômico dentro de suas comunidades. Outra "primeira obsessão" para os ameríndios em geral e ligada à questão do poderé "a noção filosófica do que significa ser similar e diferente, uma noção cujo significado básico poderia muito bem não ser o de Dênero"(Overing, 1986: 142). Encontramos um comentário visual sobre estas questões nas suas idéias sobre beleza.

Para deixar claro o que os Piaroa e Kaxinawá compartilham e onde diferem, seguirei o excmplo de Santos Granero (1986:107-31) usando os conceitos de Dumont relativos à ideologia englobante e englobado da sociabilidade. Em termos gerais, os Piaroa e os Kaxinawá, assim como outros ameríndios das terras baixas, têm idéias parecidas sobre a ética e a estética do modo de vida humana apropriado, sua ideologia englobante de sociabilidade. Mas existem diferenças de ênfase que aparecem nos seus respectivos discursos englobados.

Uma variação de ênfase é que o excesso de poder, enquanto repugnante para os Piaroa, é perigosamente atrativo e belo para os Kaxinawá, uma fascinação ligada ao desejo frustrado de transformar os semideuses canibais, os Incas, em afins. Este desejo se realizará finalmente no mundo celeste depois da morte, onde as mulheres casarão com um homem inca e homens casarão com uma mulher inca: o Inca pintsi que era gente se transforma em Inca kuin, o verdadeiro, "nosso" Inca4.

Os mitos sobre o povo inca falam de sua cultura sümente com admiração. Era um povo muito sabido, belo e sabia viver. Seus roçados eram abundantes, suas aldeias grandes e limpas. Tinham muita comida apodrecendo nos seus roçados mas nunca dariam qualquer sobra aos Kaxinawá, nem ensinariam como plantar: uma recusa total de relação de parentesco. Homens e mulheres usavam roupas tecidas com desenhos e seus rostos eram delicadamente pintados. Os Kaxinawá os consideravam muito atraentes. Os Incas costumavam convidar os Kaxinawá para dançar, mas se dançavam ou não, eles matavam uns para comer e deixavam os outros. Ajudavam as mulheres kaxinawá no parto (no tempo que os Kaxinawá ainda não conheciam o uso das plantas medicinais para o parto), devolviam as crianças aos Kaxinawá, mas comiam as mulheres. 
Apesar dos Incas , na mitologia kaxinawá, não serem associais ou amorais para com seus próprios parentes, a vida entre eles parecia até muito cultivada, eles se comportavam como monstros na sua relação com os Kaxinawá. Esta é uma visão muito relativista do moralmente bom e mal, que mostra uma consciência clara do que significa ser igual ou diferente. Os Incas os consideravam demasiadamente diferentes enquanto os Kaxinawá desejavam se tornar mais próximos em beleza, poder e conhecimento. Num dado momento, no entanto, os Kaxinawá abandonaram seu sonho de entrar em relações de troca com os Inca, mataram-nos e saíram.

O Inca mítico dos tempos de criação não é gente, é um deus. Vivia no céu e possuía a periodicidade do tempo, dia e noite, frio e calor. Era avaro com o urubu porque detestava seu cheiro, mas generoso com o gavião real com quem compartilhava seu poder sobre o céu: reparamos de novo uma sociabilidade seletiva.

Para os Kaxinawá, o Inca deus continua morando no céu e este Inca é kuin, "o próprio, nosso". O Inca pode encontrar um humano e ser visto por um humano somente para levar sua alma para sempre; nunca pode ser visitado. Jamais se retorna com vida de um encontro com o Inca (razão pela qual ninguém o vê em sonhos ou em visões com ayahuasca). Isto significa que o Inca toma a alma humana (seu espírito do olho) a partir do momento que seus olhares se cruzam. O olhar de fogo do Inca consome e transforma a alma do ser humano em habitante celeste. Assim como os Araweté humanos se tornam as esposas comidas pelos deuses (Viveiros de Castro, 1986), os Kaxinawá se tornam os cônjuges incinerados e assim eternizados dos deuses e das deusas incas. Esta escatologia é a inversão da recusa nos tempos de origem do gigante (Inca?) de receber Nete, mãe primordial do povo Kaxinawá, e seus filhos que, depois de longa viagem iniciática, chegaram ao altiplano (o barranco, a terra alta) para visitá-lo. Em vez de recebê-la como esposa (irmã), ou seja, como parente, tenta matá-la e seus filhos se vingam matando o gigante com flechinhas nos testículos enormes.

O Inca kuin que mora na aldeia celeste às vezes desce para a terra pessoalmente para levar consigo os espíritos do olho dos mortos. O caminho do Inca é um dos caminhos que a alma pode seguir indo para o céu. É um caminho largo e limpo, sem espinhos e meandros na floresta. O caminho é enfeitado com penas vermelhas, azuis, pretas e brancas. Inca hawendua, o belo Inca, usa um cocar de penas azuis, um cushma tecido com desenhos e vem tocando flauta. Os parentes do morto cantam:

\footnotetext{
"Vai para o céu, vai ficar com o Inca, vai e não volta, vai vestir a roupa do Inca, vai vestir a roupa amarela, vai, não pare no meio do caminho, vai, não volta nunca mais." (Moisés Kaxinawá, 1989).
}

Ambos, o Inca solar com o poder do jaguar - perigoso demais para ser visitado -, e o povo inca pintsibu - os Incas com fome de carne -, podem eles mesmos visitar os Kaxinawá no contexto do ritual. O Inca celeste é encenado pelo líder de canto no rito de passagem e no rito de iniciação do líder de canto, enquanto 
o povo Inca aparece nas festas damian, um tipo de teatro cômico no qual o medo que o povo canibal inspira é, através da caricatura, transformado em riso ${ }^{5}$.

Na terra e embaixo da água, o ser mais poderoso é a sucuri Dunuã, chamada Yube (o nome da lua), um ser andrógino, que combina ambos os poderes criativos masculinos e femininos. A sucuri é a dona da transformação visual e corporal porque ela possui o segredo do desenho, kene, uma arte feminina, na sua pele, e sua urina. Dunuan isun, é a bebida alucinógena ayahuasca, um agente que dá aos homens kaxinawá o poder de acesso para o lado normalmente invisível da realidade: é a presença de yuxin na natureza. En damiaki significa "estou vendo transformações, estou transformando, estou sendo transformado", um estado de mutabilidade corporal e visual criativo. Segundo Gow (The Sun, ms), "a visão é uma experiência muito visceral" para os Piaroa, o mesmo valendo para os Kaxinawá.

Yuxin é um conceito chave na visão de mundo Kaxinawá, e seus significados variados e interligados, tornam quase impossível uma tradução. Yuxin é poder ou essência ou a imagem mais completa da realidade, é força vital, assim como espírito e alma. O Inca é yuxin, a lua é yuxin, algumas plantas têm yuxin forte, assim como alguns animais. O ser humano tem vários yuxin permeando seu corpo simultaneamente. A relação entre imagem e yuxin de um lado, e yuxin e matéria de outro, nos força a reconhecer uma experiência visual entre os Kaxinawá que difere totalmente da nossa. O conceito de yuxin demonstra porque é errado falar em "representação" na criação visual Kaxinawá, mesmo quando desenham ou modelam a figura ou o padrão na pele de um animal, é porque a estética precisa ser considerada em termos de sua conexão com idéias sobre o poder.

A teoria de representação kaxinawá trata da relação entre desenho, imagem e yuxin. Um verdadeiro contato com o outro lado da realidade se torna possível somente quando os yuxin, essência espiritual, se tornam visíveis em forma humana. Na vida cotidiana o yuxin é invisível ou é visto sob outra forma, como planta ou animal. Uma foto ou retrato bem feitos são chamados de yuxin. Uma imagem é yuxin quando capta a essência da matéria, quando imagem e matéria coincidem. Assim, a representação se torna apresentação.

Algo mais que um simples reflexo de luz é trocado entre quem olha e quem está sendo olhado. O contato mais intenso com a realidade, esta e a outra, é realizado através do olho. Sons e cheiros anunciam ou evocam uma presença; a vista a confirma. Ver uma sombra na penumbra não é nunca, para os Kaxinawá, uma ilusão ótica. Mesmo passando rapidamente e somente vagamente visto, algo estava lá: yuxin. Através de yuxin a relação entre uma imagem e seu objeto é sempre de certa maneira metonímica e nunca simplesmente metafórica.

A força vital yuxin permeia todos os fenômenos vivos na terra, na água e no céu, e é esta comunhão de "yuxindade" que possibilita a comunicação, a transformação e a percepção dos yuxin pelo olhar humano. Os dois tipos de imagem que o olho humano percebe recebem nomes diferentes na língua kaxinawá: dami, um 
agente masculino e um poder de transformação, é ligado ao movimento, à figura, ao volume, ao som e ao "cinema". Kene, o conhecimento criativo feminino, é uma arte gráfica altamente padronizada cujo estilo define a identidade étnica Kaxinawá, conferindo beleza ao corpo da pessoa. Ambos os conceitos sobre a visibilidade do mundo estão no âmago da cosmovisão kaxinawá e constituem um discurso silencioso sobre a criação e transformação de corpos na luz da espiritualidade yuxin que anima a matéria. A arte dami, mutabilidade corpórea, e a arte kene, tecendo uma unidade cultural kuin com o natural-sobrenatural, são dois caminhos mediadores entre o lado visível e invisível da realidade, que demonstram o que o mundo humano, de uma maneira especifica - kuin - tem em comum com o mundo não-humano. Arte e xamanismo se encontram onde o dualismo entre matéria e espírito deixa de existir: a arte revela o espirito na matéria, o xamanismo a matéria no espírito.

Uma comparação desta filosofia kaxinawá concernente à natureza do poder vital com a dos Piaroa revela uma teoria englobada sobre a natureza do mundo bastante diferente. A teoria piaroa parece perfeitamente platônica quando trata da criatividade transformacional no tempo histórico. Sua interpretação do poder criativo nos tempos míticos, quando o mundo foi criado, no entanto, compartilha da visão englobante dos Kaxinawá sobre a mutabilidade da matéria e das formas corpóreas quando permeadas pelo poder espiritual de um excesso de conhecimento.

No tempo histórico, as condições para a criação da vida são separadas no espaço: a totalidade do conhecimento, "a vida dos pensamentos" (the life of thoughts), é guardada pelos deuses celestiais em suas caixas de cristal onde a água enluarada das cachoeiras limpa estes poderes constantemente. Nas caixas de cristal, livre de qualquer contaminação pela matéria, o poder é lindo. Os deuses são perfeitos, mas enquanto guardiães de conhecimento (a idéia perfeita se torna Um com a imagem e o canto perfeitos das cachoeiras eternas) eles são impotentes, incapazes de criar corpos, isto é, vida.

Mas "a vida dos sentidos" (the life of the senses), que parece estar associada com o poder do sangue e do desejo e que anseia ter um corpo, existe somente na terra. Os animais só têm uma "vida dos sentidos". O agente poderoso aqui é o agente humano por combinar a "vida dos pensamentos" com a "vida dos sentidos". Assim, a condição humana é a realização única da vida cultural, o conhecimento de criar uma vida comunitária através do conhecimento e desejo controlados. Sabedoria é saber quanto conhecimento (extremamente perigoso na sua forma essencial) alguém sabe agüentar sem enlouquecer. Loucura torna a vida em comunidade impossível pelo comportamento incontrolado da fúria e da paranóia, matando e comendo gente, cometendo incesto, roubando etc.

É exatamente isto que aconteceu com os deuses criadores antes da separação dos poderes. O excesso de conhecimento, o conhecimento que lhes possibilitou inventar e criar o mundo, envenenou-os e tornou a vida na terra impossível. Os dois demiurgos, Kuemoi e Wahari receberam seus respecti- 
vos poderes transformacionais da tapir-sucuri através de tipos diferentes de drogas. Kuemoi, dono dos seres aquáticos, era o mais criativo e também o mais envenenado. Era horrível. Wahari, dono dos seres da floresta, queria transformar as criações selvagens e destrutivas de Kuemoi em cultura para seu povo piaroa, mas também se envenenou e matou Kuemoi, seu cunhado. Esta foi a razão da sua própria morte nas mãos de seus parentes.

Um fato importante da crença englobante sobre poder é que para ambos - os Kaxinawá e os Piaroa - a origem de todo poder criativo vem da sucuri (tapir). O dualismo e a complementaridade expressos neste mito piaroa é a do poder florestal/voador versus o poder aquático, que o ser supremo combina e divide entre os demiurgos, que iniciam uma luta ciumenta para conquistar o que foi dado ao outro. Apesar do demiurgo florestal Wahari não ser um santo, a oposição entre ele, inicialmente bom e bonito, e Kuemoi, o terrível, feio e ridículo, parece ser de caráter moral. A natureza complementar dos poderes criativos nos mitos kaxinawá sobre a sucuri, por outro lado, não é nem moral nem espacial, mas de gênero. A anaconda andrógina dá aos homens o dami, o poder de modelar formas na fertilidade assim como no seu contato com o lado yuxin da realidade, e às mulheres o kene, o conhecimento de controlar e domesticar a forma através do desenho na superfície da pele, abrindo, fechando e protegendo desta maneira o interior do corpo (o humano assim como o corpo social) da intrusão perigosa mas vital do yuxin estrangeiro. As paredes da casa também são chamadas de kene, sendo para a comunidade o que a pele com desenho é para o corpo.

Para os Piaroa, a condição humana parece representar o estado ideal do ser. Os humanos são os únicos seres a combinar as forças criativas e o conhecimento para produzir vida cultural na terra. Mas este conhecimento criativo pode existir somente porque a fonte do poder está localizada prudentemente fora da sociedade e fora do mundo material. O xamã ${ }^{6}$ é o viajante treinado que vai ao céu para pegar pedaços controlados de conhécimento e os introduz nos corpos de seus parentes, nas suas contas (miçangas) invisíveis de conhecimento: as roupas internas do indivíduo. Ele também viaja para o mundo subterrâneo para persuadir o dono dos animais a transformar seus parentes humanos em forma animal para serem caçados na terra.

Os Kaxinawá, por outro lado, parecem interpretar a condição humana como menos poderosa que a de outros seres que não têm gênero nem são mortais, como a sucuri e o Inca. A sexualidade e a fertilidade são consideradas como inseparáveis da mortalidade e vulnerabilidade. O estrangeiro é quem tem o poder que eles carecem; é impossível viver sem este outro perigoso.

Como os Piaroa, os Kaxinawá situam a fonte de poder fora da comunidade, mas não a exilam deste mundo. A força vital, yuxin, em suas várias manifestações, está inexplicavelmente ligada com a matéria. A noção Kaxinawá da natureza com intencionalidade (sede da possibilidade de um número infinito de mundos 
culturais e sobrenaturais) está mais perto da noção grega de physis (uma natureza com alma e vontade ameaçadora, mas que está ao mesmo tempo dentro da polis ordem específica conquistada sobre o caos do desconhecido) que da noção cristã de natureza contra o espírito ${ }^{7}$. Para os Kaxinawá, a cultura é simplesmente uma escolha idiossincrática entre várias outras ordens possíveis, uma escolha que marca sua identidade étnica e os distingue de outros humanos. O humano existe dentro da natureza, reconhecendo características de sua cultura verdadeira, kuin, em certos hábitos, sons e desenhos de animais e espíritos escolhidos, parentes.

\section{"Sem yuxin a coisa se torna Pó" (Antônio Pinheiro dua bake KAXINAWÁ, 1989)}

O mito de criação dos Kaxinawá liga a transgressão da condição humana sexuada à criatividade suprema. Nete, a única sobrevivente do grande dilúvio, se tornou a ancestral dos Kaxinawá fertilizando a si mesma, cuspindo no seu próprio ventre: dominava ambos os poderes femininos e masculinos de fertilidade. Cuspir e sugar são para os Kaxinawá, assim como para muitos povos ameríndios, meios poderosos de transferir energias na cura como no processo de causa de doença. A combinação de ambas as criatividades femininas e masculinas aumenta enormemente o poder do xamã.

Três mitos relacionados que tratam da sucuri falam do poder sedutor do desenho para os homens. No mito que conta a origem do conhecimento masculino sobre o uso da ayahuasca e seus cantos, um homem vê como uma bela mulher, toda pintada com desenhos delicados em jenipapo, sai do lago, chamada por seu amante, a anta. O homem ficou tão impressionado pelo que viu que decidiu fazer o mesmo. A mulher-sucuri aceita fazer amor com ele sob a condição de que ele a siga para viver com ela e seus parentes embaixo da água. Lá ele aprende como preparar a ayahuasca, mas não agüenta o medo de seus novos afins se transformando em sucuris. Gritando seus nomes, ele os insulta e se vê obrigado a fugir do perigo de ser morto pelo sogro e seus cunhados. Mais tarde acaba sendo ferido pelos filhos e pela mulher sucuris, e sentindo que vai morrer, resolve ensinar a seu povo o conhecimento precioso da transformação visual, conquistado na sua aventura exogâmica.

Este mito elabora os mesmos problemas que os mitos sobre os Incas: a dificuldade de transformar afins potenciais em afins reais e parentes, assim como a ligação entre conhecimento, poder e beleza sedutora.

O encontro com a sucuri, cujos belos desenhos impressionavam os Kaxinawá, teve um resultado diferente para os homens e as mulheres. Um homem encontrou a sucuri e a matou para levar sua pele. O yuxin da sucuri lhe perguntou "por que você me matou? Não lhe fiz nada". O homem respondeu, "eu estava com inveja da sua pintura". A sucuri lhe deu seu nome, Yube, que é também o nome da 
lua e imbuiu o homem com o poder yuxin que o possibilitou visitar os mundos normalmente invisíveis: dami (Capistrano, 1941: 523).

Uma velha viu a sucuri e falou: " - Cunhada me ensine seus lindos desenhos." A sucuri estava tecendo e disse: "- Vem aqui, sente-se, olhe e escute meu canto". Por isso são as mulheres que possuem o desenho e não os homens. Mas quando a velha sentia que ia morrer, ela só tinha um filho homem vivendo com ela e o ensinou os desenhos femininos. Napu Ainbu, quando chegou na aldeia dos seus parentes depois da morte da mãe, sabia tão bem desenho que se tornou irresistível para seus parentes. Mesmo depois de ter sido informado que ele era de fato um homem e não uma mulher, um dos homens insistia tanto para fazer o amor com Napu Ainbu que este cedeu e engravidou. A abertura para a criança sair, no entanto, era pequena demais, e Napu Ainbu acabou morrendo ${ }^{8}$.

A inveja que os homens têm do desenho é ligado ao seu desejo e dependência das mulheres para procriar (enquanto mulheres, teoricamente, podem engravidar através de contato com yuxin). A sucuri se chama Yube. A história de Yube, o irmão incestuoso que, depois de morto, tornou-se lua porque não queria ser esquecido pelas irmãs, é sobre a origem da menstruação e da fertilidade. A menstruação, a lua e a cobra estão ligados através de suas mudanças cíclicas.

A sucuri tem vida eterna porque troca de pele e mulheres são férteis porque trocam sua pele ou roupa interna. Neste contexto, a associação lingüística entre desenho e placenta é significante. Xamanti é um motivo usado com frequiência na tecelagem de redes, xaman significa placenta; e tecer com desenho é xankeikiki, xankin significa útero.

A placenta, entre o feto e o corpo materno, filtra as influências de fora e protege o interior, assim como possibilita um contato controlado com o exterior que é a fonte da vida. Da mesma maneira a pele da sucuri coberta com desenho serve de véu entre o mundo visível e invisível. Os desenhos aparecem no espaço liminar de onde o espírito do olho é levado de um lado da realidade (o lado da luz solar) para o outro lado oculto, pronto para se revelar no crepúsculo. Ninguém procura a cobra de dia.

As palavras dos cantos masculinos da ayahuasca são muito explícitos com relação a esta função liminar e mediadora do desenho ria sua viagem para o mundo dos yuxin. No início, no entanto, os desenhos aparecem girando como redemoinhas e causando medo: são o couro da sucuri se aproximando. Iniciantes são pegos pelo medo. Acreditam que vão morrer porque a cobra quer comê-los. Depois de comer o noviço, a sucuri o vomita na areia branca da praia do rio, onde escuta seus parentes cantando e chamando-o. A partir deste momento vê que os desenhos traçam um caminho pelo céu que tem que seguir para não se perder. Os desenhos femininos são o caminho que leva os homens kaxinawá para os seres celestes e os mostra o caminho de volta. O mestre de canto canta:

"Nossas palavras como desenho. Você vê o canto, ele vai te procurar longe. O olho do céu com desenho, estamos no caminho certo. Não está errado, está clareando 
agora. O cipó forte tem pena da gente, escutando o canto da sucuri. É um sonho, olhando, não vai mais longe. Mas agora o cipó forte entra seu corpo, ele está bem aí, no meio, você vê tudo, bem no meio. A força do cipó forte é como fazer desenhos. Agora o cipó fica deitado. Estou cantando, você pode me escutar de longe, vem, vem, para perto de mim." (Antônio dua bake Kaxinawá, 1991).

É uma coincidência interessante que os rapazes piaroa na sua iniciação com alucinógenos também têm que visualizar caminhos a seguir através dos cantos que escutam: "eles têm que conseguir ver as palavras... [e] ver o caminho das contas" (Overing, 1988:185). Também aprendem a perceber que "o desenho era um caminho, ou a ordem das palavras e dos cantos" (Overing, 1989). Os Kaxinawá também associam as contas (miçangas) se não com caminhos, pelo menos com o conhecimento da boa visão, como fica clara no seguinte texto de um canto de iniciação:

"coloque miçangas nos meus olhos, vou fazer uma pulseira para minha avó. Quero fazer meus olhos como miçanga" (Teresa inani bake Kaxinawá, 1991).

A "menstruação" masculina durante as cerimônias de ensinamentos xamânicos segue uma lógica paralela à da necessidade do desenho feminino para o homem encontrar seu caminho no universo. A prática ritual demonstra que, também para os Piaroa, a interdependência dos poderes criativos de gênero é um credo englobante:

\footnotetext{
"O mestre xamã perfura a língua do aprendiz com a espinha da arraia, e o sangue que sai é o sangue menstrual das mulheres com as quais ele tinha vivido na sua casa... Os homens precisam da transferência para si das capacidades criativas femininas para que eles mesmos possam se tornar criativos, o inverso do caso do mito onde as mulheres receberam seus poderes criativos de Buok'a, um homem."(Overing, 1986:149).
}

As mulheres kaxinawá também receberam seus poderes criativos (menstruação-fertilidade) de um homem, Yube a lua, enquanto a "menstruação" masculina se torna possível pela beberagem da sucuri. No canto, a bebida é chamada de sangue e no céu está o mel, associado ao sêmen. Com estes fluidos poderosos no estômago, o aprendiz "engravida" de novos mundos:

"Meu filho de criação, vamos esquentar o cipó, o poder do cipó, secar.

Novo na barriga do homem. Vamos andar, faz tempo que tomamos o forte e não passa.

A força está subindo e quebrando galhos (para saber o caminho).

O forte clareia como luz, meu filho adotivo, o céu está vermelho, o forte é vermelho.

O homem o engole em seu ventre, dentro do homem, o céu vermelho.

Faz tempo que tomamos a força do nixi pae, mas ainda está forte.

Raspe a força do nixi pae e tome. Já passou tempo desde que você raspou o forte.

Vira mulher, estica mulher, o poder esticado do nixi pae.

Meu corpo está cantando, girando como um pedaço de madeira queimando.

O homem vai virar mulher. Vai preparar comida.

A mulher quer preparar comida, se estica e se foi... 
Lá no céu o menino nambuã. O mel do céu é doce, ele o toma todinho

Está muito doce agora na nossa barriga, raspe e tome.

Na nossa raiz, você na raiz do nixi pae,

outro mundo está saindo, gente saindo do meu ventre..."

(Leôncio dua bake Kaxinawá, 1991).

Outra idéia englobante, comum à estética piaroa e kaxinawá, é que a essência do poder é sempre criativa e destrutiva ao mesmo tempo, e que a verdadeira natureza tanto da cultura quanto da vida é predatória.

Os Piaroa chamavam o "espírito do canto" do seu xamã "o espírito da fome" e o espírito do alucinógeno yopo, "o espírito da guerra". "Tradicionalmente, as contas dos ornamentos usados pelos Piaroa eram feitas de um tipo de granito especial que diziam ser o afloramento das fezes da divindade mais poderosa $\mathrm{e}$ perigosa do universo, o tapir/sucuri" (Overing, 1989: 169), estas contas expressam a perigosa "vida dos sentidos" da pessoa.

O poder da "vida dos pensamentos" era também expresso em termos de perigo através das pinturas faciais: um destes desenhos, kérau paratami, significava "doença da loucura". A quantidade de contas que alguém usa, assim como sua pintura corporal e facial, reflete na superfície do corpo a quantidade de conhecimento que uma pessoa guarda no seu interior. Este poder, venenoso na sua origem, torna-se bonito através da limpeza do luar, nos cantos noturnos do xamã e pelo controle pessoal do dono das contas, cujo desejo pela ligação com pessoas é maior que sua vontade de poder ilimitado.

Estar coberto com desenho, para os Kaxinawá, significa estar forte, duro e amargo o suficiente para se engajar em relações produtivas que implicam um contato direto com as forças yuxin. O desenho é a visibilidade domesticada e controlada dos yuxin; seu padrão labiríntico filtra as forças selvagens do yuxin que o adulto tem que enfrentar.

Uma criança recém-nascida, quando sai pela primeira vez da rede da mãe, é pintada de preto: a criança é ainda mole e doce demais para ser vista pelos yuxin. Quando estão um pouco mais velhas, crianças pequenas recebem o desenho específico xapu buxe (semente de algodão), para as meninas aprenderem a tecer com facilidade; e kuma tae (pé de nambu), para que os meninos aprendam a correr ligeiro. Até a iniciação, os rostos das crianças nunca são inteiramente cobertos com desenhos verdadeiros. Usam yaminahua kene, desenho com nome de seus vizinhos do mesmo tronco lingüístico pano. Este nome se refere a estrangeiros, mas não estrangeiros "de verdade" (porque os Kaxinawá consideram os Yaminahua como parte dos povos verdadeiramente huni kuin, mas não como parentes reais: nukun yuda, nosso corpo). Os nomes dos motivos são "inocentes": flor, borboleta, coração, estrelas.

O desenho verdadeiro, kene kuin, usado nos adultos, é geralmente chamado de nawan kene, desenho de inimigo. Neste repertório se encontram o desenho inu tae (pata de onça) e kape hina (rabo de crocodilo), os animais mais perigosos da 
floresta além da cobra. Estes motivos e muitos outros foram dados pela sucuri (Lagrou, 1991). Estes poucos exemplos deveriam bastar para mostrar que também entre os Kaxinawá, apesar do estilo gráfico ser uma marca crucial que usam orgulhosamente para definir o nukun yuda - nosso corpo (social) -, os nomes dos desenhos se referem à origem estrangeira de seu poder.

Apesar de suas visões complexas e contraditórias sobre o poder e o que significa ser similar ou diferente, o estilo gráfico dos Kaxinawá enfatiza claramente a visão ameríndia englobante da sociabilidade, em que a autonomia pessoal se manifesta em detalhes idiossincráticos sutis, escondidos num padrão global de simetria e igualdade. O efeito studium-punctum de Roland Barthes (1980) se aplica bem a este tipo de estilo.

O studium, ou discurso dominante, seria, neste caso, a repetição de elementos iguais num ritmo simétrico e um grande valor dado à execução de linhas finas e paralelas. Os Kaxinawá "sofrem" de horror vacui : a superfície inteira do corpo pintado precisa ser coberta com desenho e nenhuma linha pode ser deixada em aberto. $\mathrm{O}$ padrão pode ser cortado onde a superfície pintada pára, sugerindo a continuação do padrão em outros corpos. Esta característica do estilo sugere a função do desenho como algo que une em vez de separar. O desenho visualiza a qualidade yuxin que permeia o mundo natural, supernatural e cultural dos Kaxinawá, separando-os dos povos sem (olho para) desenho.

O punctum é um detalhe dissonante, quase imperceptível, uma surpresa, necessária para que a dinâmica visual dê vitalidade estética ao conjunto, podendo manifestar-se como uma pequena diferença na repetição do padrão, um ponto assimétrico dentro da simetria. É preciso uma certa homogeneidade nos elementos visuais para que a pequena diferença possa tocar o olhar. A arte kaxinawá explora de maneira muito elegante este entrelaçamento de studium e punctum. Esta marca sutil da personalidade do artista numa obra tão fortemente marcada pelo estilo me parece congruente com a maneira pela qual os Kaxinawá experimentam a vida: criar uma comunidade é fruto de um forte desejo de viver juntos, tranquiilamente, com parentes próximos, tornando a sociabilidade possível através da autonomia pessoal e pelo respeito à autonomia do outro.

"Quem não sente falta dos seus parentes, como se sente falta de água, não é gente. É que nem espírito que fica vagando por aí.” (Antônio dua bake Kaxinawá, 1989).

\section{Notas}

1 Este artigo é a tradução de um paper apresentado como conclusão do curso "Production and Exchange among the Indigenous Peoples of South America", oferecido pela Prof. a Joanna Overing em 1992 na USP. A tradução, tanto do texto quanto das citações, é minha. 
2 Charbonnier (1961:63-91), faz uma primeira tentativa de analisar de um ponto de vista antropológico a diferença entre arte moderna e "primitiva". Lévi-Strauss coloca que nossa tradição intelectual ocidental é responsável por três diferenças entre arte "acadêmica" e arte "primitiva", diferenças que a arte moderna tenta superar: 1 . A individualização da arte ocidental, especialmente no que diz respeito a sua clientela, que provoca e reflete uma ruptura entre o indivíduo e a sociedade em nossa cultura - um problema inexistente para o pensamento indígena sobre socialidade; 2 . A arte ocidental seria representativa e possessiva enquanto a arte "primitiva" somente pretenderia significar; 3 . A tendência na arte ocidental de se fechar sobre si mesma: "peindre après les maîtres". Os impressionistas atacaram o terceiro problema através da "pesquisa de campo" e os cubistas o segundo, recriando e significando em vez de tentar imitar de maneira realista - aprenderam das soluções estruturais oferecidas pela arte africana-; mas a primeira e crucial diferença, a da arte divorciada do seu público, não pôde ser superada e resultou num "academicismo de linguagens": cada artista inventando seus próprios estilos e linguagens ininteligíveis.

3 A relação da arte com a realidade social é similar à do ritual como proposta por McCallum (1989): que violência ritual contra mulheres não pretende "representar" a violência na vida cotidiana nem vice-versa. O mesmo se vê na interpretação por LéviStrauss da representação desdobrada nas pinturas faciais Kadiwéu. Em vez de refletir uma estrutura social de metades, o desdobramento do desenho em duas metades nos informaria sobre o desejo dos Kadiwéu de superar a tensão social inerente ao seu sistema de três castas, uma tensão temporariamente dissolvida pela imaginação artística.

4 Veja Bastos (1989) para uma análise etnográfica da interpretação conflitiva do mito encenado na "festa da jaguatirica", expressada pelo ritmo e pela melodia da música de um lado e o texto da música de outro.

5 Veja Capistrano de Abreu (1941) para a mais completa coleção de mitos Kaxinawá; Lagrou (1991) para os mitos discutidos neste texto; veja também Kensinger (1986), McCallum (1992) sobre os mitos sobre o Inca entre os Kaxinawá.

6 Na festa do damian que assisti em 1991, seringueiros bêbados tinham substituído os Incas canibais. Veja também McCallum (1992:14).

7 Overing usa a palavra wizard em inglês, mas a palavra mago não soa como wizard, por isso a traduzi como xamã.

8 Veja Bastos (1989: 283) onde discute a semelhança entre a noção grega "dionisíaca" da physis e a noção kamayura da natureza "divina".

9 Veja capítulo xiii, "Grafismo (kene) e Xamanismo (dami)"da minha dissertação de mestrado, Uma etnografia da cultura kaxinawá: Entre a cobra e o Inca (1991), para uma análise mais extensiva destes três mitos da sucuri e para os mitos de iniciação para as mulheres para aprenderem desenho e para os homens para aprenderem a tomar ayahuasca, chamado de nixi pae, cipó forte, ou huni, pessoa humana: o agente revela yuxin como seres humanos. 


\section{BibLIOGRAFIA}

BASTOS, R.J.M.

1989 A festa da jaguatirica: Uma partitura crítico-interpretativa, tese de Doutorado, São Paulo, Departamento de Antropologia, USP.

\section{BARTHES, R.}

1984 A câmara clara. Rio de Janeiro, Nova Fronteira.

\section{CAPISTRANO DE ABREU}

1941 (1914) Rã -txa hu-ni-ku i: A língua dos caxinauás do rio Ibuaçu, afluente do Muru, Rio de Janeiro, Leuzinger.

1969 (1912) "Os Caxinauá”. In: Ensaios e Estudos, pp.174-225.

\section{CLASTRES, $\mathrm{P}$.}

1974 La société contre l'État, Paris, Ed. Minuit.

\section{CHARBONNIER,C.}

1961 Entretiens avec Claude Lévy-Strauss, Paris, Plon.

\section{GEERTZ, C.}

1983 "Art as a Cultural Systhem".In: Local Knowledge: further essays in interpretative anthropology, New York, Basic Books, pp. 94-121.

GOW, P.

ms Sun (rough draft).

1988 "Visual Compulsion: Design and Image in Western Amazonian Culture". In: Revindi, pp. 19-32.

1991 Mixed blood: kinship and history in peruvian Amazonia.

KENSINGER, $\mathrm{K}$.

1986 When a turd flotes by: Cashinahua methaphors of contact, AAA symposium.

LAGROU, E.

1991 Uma etnografia da cultura kaxinawá: entre a cobra e o Inca, dissertação de Mestrado, Florianópolis, UFSC.

LÉVY-STRAUSS, C.

1955 Tristes Tropiques, Paris, Plon.

McCALLUM, C.

1989 "Vampire bats and Totoise necks. Are analysis of 'rituals of sexuall antagonism"”, In: Amazonia.

1992 "Our own Incas: production, transformation and transcendenc in Cashinahua history", a ser publicado em B. Albert and A. Ramos (eds.). 


\title{
OVERING, J.
}

1985 "There is no end of evil: the guilty innocents and their fallible god". In: PARKIN (ed.), pp. 244-78.

1986a "Men control women? The 'Catch 22' in gender analysis". In: International Journal of Moral and Social Studies, Vol.1, part 2, pp. 135-56.

1986b 'Images of cannibalism, death and domination in a 'non-violent' society .In: Journal de la Société des Américanistes, LXXII, Paris, pp. 133-56.

1988 "Personal autonomy and the domesticaton of self in Piaroa society". In: JAHODA, G. \& LEWIS, I.M. (eds.). pp. 169-92.

1989 "The aesthetics of production: the sense of comunity among the Cubeo and Piaroa", In: Dialectical Anthropology, Amsterdam, Elsevier Scientific Publishing, 14: 159-75.

1990 "The shaman as a maker of worlds: Nelson Goodman in the Amazon". In: Man (N.S.) 25: 601-19, Royal Anthropological Institute of Great Britain and Ireland, Londres.

1992 "The anarchy and collectivism of the 'primitive other': Marx and Sahlins in the Amazon". In: HANN, C. (ed.).

"I saw the sound of the waterfall", ms.

1992 "Death and the loss of civilized predation among the Piaroa of the Orinoco Basin". ms.

\section{SANTOS GRANERO}

1986 "The moral and social aspects of equality amongst the Amuesha of Central Peru", In: Journal de la Société des Américanistes, LXXII:107-31.

\section{VIVEIROS DE CASTRO, E.}

1986 Os Araweté, os deuses canibais, Rio de Janeiro, Jorge Zahar.

\begin{abstract}
In this article, the esthetical concepts of Piaroa and Kaxinawa and the role they play in their societies are compared. "Art" and esthetic, because they interect with other simbolic systems (the music, the ritual and the social organization), allow us to understand the way the power, the knowledge and the kinship are conceived in those societies.
\end{abstract}

Uniterms: etnology, esthetics, power, knowledge, Kaxinawá, Piaroa. 


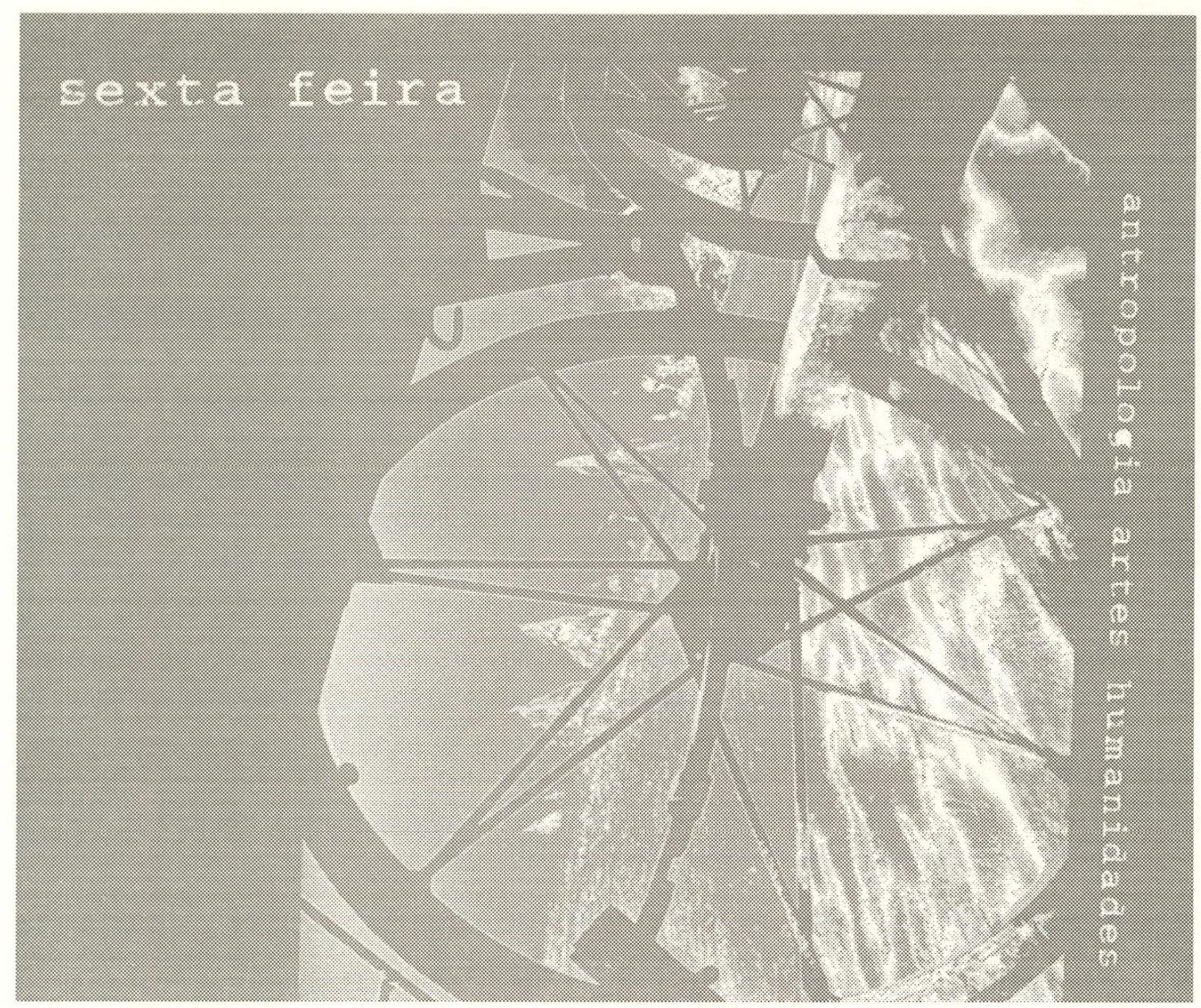

Sexta Feira traz temas variados relacionados à Antropologia contemporânea.

As fronteiras entre arte e ciência, documentário e ficção, imagem e texto são algumas das tópicas abordadas neste primeiro volume.

Convida-se o leitor a uma aventura prazeirosa pelas províncias da disciplina.

Envie seu pedido para:

Laboratório de Imagem e Som em Antropologia

Rua do Anfiteatro, 181

Cj. Colméias - favo 8

Cidade Universitária - São Paulo - SP

CEP 05508-900 